\section{Stereoselective Deoxygenation of Erythromycin A at C-12: Effect of Structure and Conformation on Prokinetic Activity}

\author{
Paul A. Lartey*, Ramin Faghth, \\ Thomas Pagano, Hugh N. Nellans, \\ Albert Petersen and Jacob J. Plattner
}

Pharmaceutical Discovery Division, Abbott Laboratories, Abbott Park, IL 60064, U.S.A.

(Received for publication March 1, 1995)

The macrolide antibiotic erythromycin A $\mathbf{1}$ is a potent Gram-positive antibacterial agent. Pioneering studies by OMURA et al., ${ }^{11}$ demonstrated that its 8,9-anhydro-6,9hemiacetal (enol ether) derivative 2 has diminished antibacterial activity but is a potent motilin receptor agonist (motilide). ${ }^{2)}$ As such 2 induces contractions in the smooth muscle of the gastrointestinal (GI) tract of dog and is potentially useful as a GI prokinetic agent. In an effort to extend the SAR of the motilides, we decided to determine the effect of C-12 deoxygenation of $\mathbf{2}$ on both antibacterial and prokinetic activities. The deoxy congener with the natural $(R)$ configuration at C-12 4 is synthetically accessible ${ }^{3)}$ from erythromycin B 3 , but in order to obtain the (S)-epimer, we had to devise methodology for selective deoxygenation of $\mathbf{1}$.

The 12-OH of $\mathbf{1}$ is hindered and inaccessible selectively, therefore our strategy was to take advantage of the reactivity and $s y n$-orientation of the vicinal $11-\mathrm{OH}$ to prepare an 11,12-cyclic thionocarbonate. In accordance with BARTON and MCCOMBIE, ${ }^{4}$ a tributylstannyl radical should attack the thiocarbonyl group to generate a radical intermediate which, in this case, could fragment to the secondary radical at $\mathrm{C}-11$ or the tertiary radical at $\mathrm{C}-12$. Since tertiary radicals are more stable than secondary radicals and react faster in both fragmentation and hydrogen abstraction reactions, ${ }^{5,6)}$ we hoped that the Barton-McCombie deoxygenation would be selective for $\mathrm{C}$-12, to give epimeric 12-deoxy congeners.

Thus the $2^{\prime}-\mathrm{OH}$ and $4^{\prime \prime}-\mathrm{OH}$ groups were sequentially and selectively protected with an acetyl and a benzyloxycarbonyl group respectively (Scheme 1) to provide $\mathbf{5}$. Treatment of 5 with thiophosgene gave the 11,12-cyclic thionocarbonyl-6,9-hemiacetal intermediate 6. Deoxygenation of $\mathbf{6}$ with tri- $\mathrm{N}$-butyltin hydride was regioselective for $\mathrm{C}-12$, but to our surprise, enol ether 8 with the unnatural $(S)$-configuration at $\mathrm{C}-12$ was the exclusive deoxygenation product. Hence conditions for the deoxygenation had also resulted in the elimination of the hemiacetal hydroxy group at C-9 of $\mathbf{6}$ to generate the enol eher. On the other hand, prior conversion of 6 to enol ether 7 , followed by treatment with tri- $n$-butyltin hydride afforded compound 9 with the natural configuration at $\mathrm{C}-12$. These results also demonstrate that formation of the enol ether from 6 occured after the C-12 deoxygenation and that the hemiacetal $\mathrm{OH}$-group played a role in directing the stereoselectivity of the deoxygenation. Removal of the protecting groups in $\mathbf{8}$ and $\mathbf{9}$ by treatment with methanol followed by hydrogenolysis afforded 10 [MS $\left.m / z 400\left(\mathrm{M}^{+}\right)\right]$and 4 respectively, thereby confirming $\mathrm{C}-12$ stereochemistry for $\mathbf{9}$.

The ${ }^{1} \mathrm{H}$ resonances for the novel 12-epi compound 8 are compared with those of 9 in Table 1 . From the COSY spectrum of 8 , the protons pertinent to the determination of C-12 stereochemistry were at $\left(500 \mathrm{MHz}, \mathrm{CDCl}_{3}\right)$ $\delta 5.55\left(1 \mathrm{H}, \mathrm{d}, J_{11.10}=5.5 \mathrm{~Hz}, 11-\mathrm{H}\right), 5.07(1 \mathrm{H}, \mathrm{dd}$, $\left.J_{13,12}=7.5 \mathrm{~Hz}, J_{13,14}=6.0 \mathrm{~Hz}, 13-\mathrm{H}\right), 3.57(1 \mathrm{H}, \mathrm{m}$, $10-\mathrm{H}), 2.77(1 \mathrm{H}, \mathrm{m}, 12-\mathrm{H}), 1.69(2 \mathrm{H}, \mathrm{m}, 14-\mathrm{H}), 1.19(3 \mathrm{H}$, $\left.\mathrm{d}, J_{21,12}=4.8 \mathrm{~Hz}, 21-\mathrm{H}\right), 1.09\left(3 \mathrm{H}, \mathrm{d}, J_{20,10}=5.0 \mathrm{~Hz}\right.$, 20-H). In the NOESY spectrum, a strong NOE was observed between $13-\mathrm{H}$ and $11-\mathrm{H}$, suggesting a diaxial arrangement for the two protons. There is also a weak NOE between $20-\mathrm{H}$ and 11- H. A weaker NOE between $11-\mathrm{H}$ and $12-\mathrm{H}$ suggests a pseudo-equatorial orientation for $12-\mathrm{H}$, hence an axial $21-\mathrm{H}$. These NOEs were consistent with the proposed conformation $\mathbf{1 1}$ for $\mathbf{8}$, in which the methyl groups C-20 and C-21 are in a 1,3-gauche relationship.

The pertinent resonances in the COSY spectrum for 9 were $\delta 5.14(1 \mathrm{H}, \mathrm{m}, 13-\mathrm{H}), 3.36(1 \mathrm{H}, \mathrm{m}, 11-\mathrm{H}), 2.61$ $(1 \mathrm{H}, \mathrm{m}, 10-\mathrm{H}), 1.66\left(1 \mathrm{H}, \mathrm{dd}, J_{14 \mathrm{a}, 13}=5.0 \mathrm{~Hz}, J_{14 \mathrm{a}, 14 \mathrm{~b}}=\right.$ $15 \mathrm{~Hz}, 14 \mathrm{a}-\mathrm{H}), 1.65(1 \mathrm{H}, \mathrm{m}, 12-\mathrm{H}), 1.48(1 \mathrm{H}, \mathrm{m}, 14 \mathrm{~b}-\mathrm{H})$, $1.04\left(3 \mathrm{H}, \mathrm{d}, J_{20,10}=4.5 \mathrm{~Hz}, 20-\mathrm{H}\right), 0.83(3 \mathrm{H}, \mathrm{d}$, $\left.J_{21,12}=5.0 \mathrm{~Hz}, 21-\mathrm{H}\right)$. The ROESY spectrum for 9 showed NOEs from $21-\mathrm{H}$ to $10-\mathrm{H}$ and to $11-\mathrm{H}$. There was also an NOE between $11-\mathrm{H}$ and $13-\mathrm{H}$, consistent with conformation 12. Conformation 12 is similar to the $\mathrm{X}$-ray crystallographic structure reported ${ }^{7)}$ for $(9 R)-9$ dihydro-6,9-anhydroerythromycin A. This conformation may have been less favored in the case of $\mathbf{8}$, since it would have put $\mathrm{C}-20$ and $\mathrm{C}-21$ in a 1,3-diaxial relationship.

The activity of 10 was compared to 4 in a rabbit duodenal smooth muscle contractility assay, which serves as an in vitro evaluation of prokinetic potency. Compound 10 was much weaker $\left(\mathrm{pED}_{50}=7.0\right)$ than 4 $\left(\mathrm{pED}_{50}=8.7\right)$. Hence, epimerization at $\mathrm{C}-12$ with concomitant conformational change around the $\mathrm{C}-10$ to $\mathrm{C}-13$ region of the macrolactone resulted in a significant decrease in prokinetic activity. The in vitro antibacterial activity of $\mathbf{1 0}$ as well as its 9-ketone analog (12-
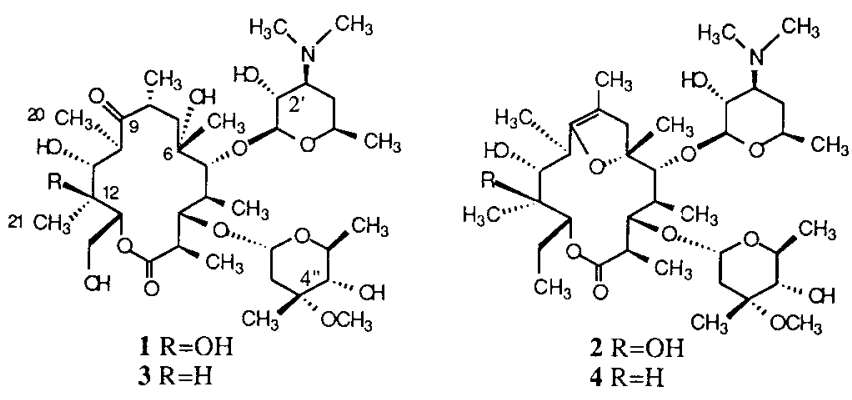

This manuscript is a special contribution in honour of Professor SATOSH ŌMURA's 60th birthday. 
Scheme 1.

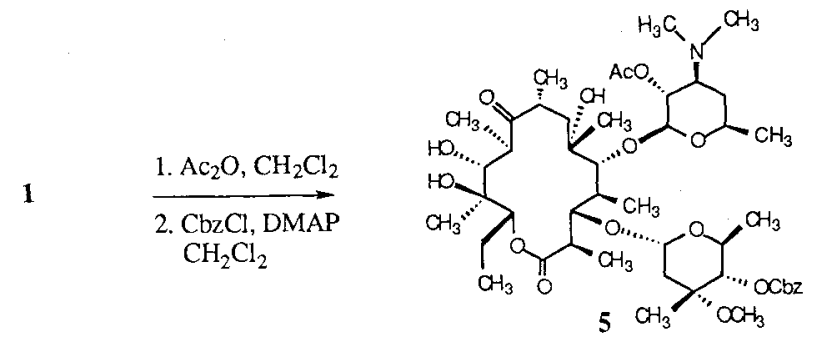

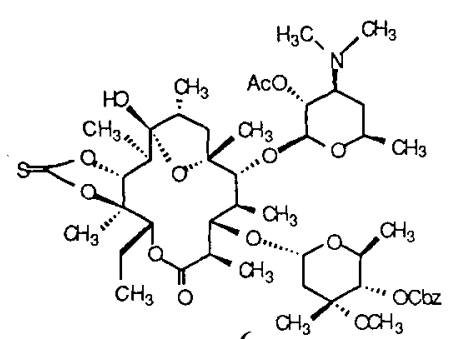

6

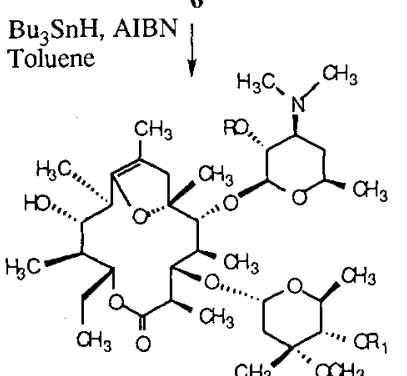

1. $\mathrm{MeOH}-8 \mathrm{R}=\mathrm{Ac}, \mathrm{R}_{1}=\mathrm{Cbz}$

2. $\mathrm{H}_{2} / \mathrm{Pd}, \mathrm{C} \longrightarrow 10 \mathrm{R}=\mathrm{R}_{1}=\mathrm{H}$

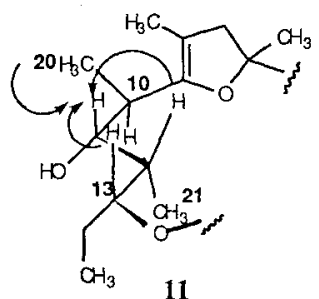

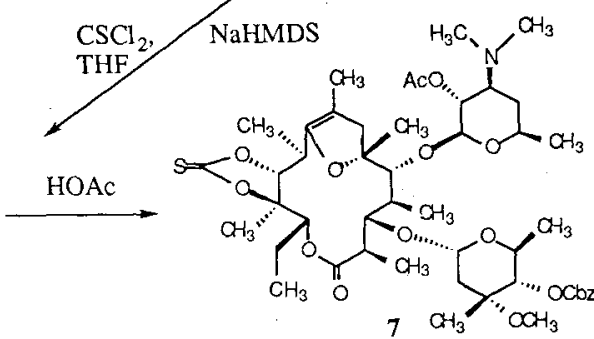

$\mathrm{Bu}_{3} \mathrm{SnH}, \mathrm{AIBN}$

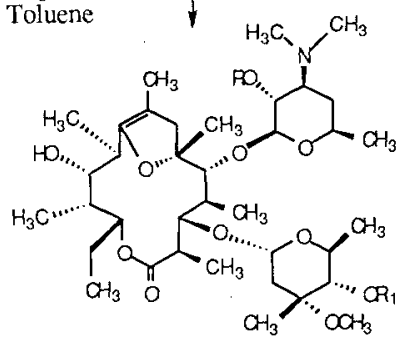

1. $\mathrm{MeOH} \quad \square \mathrm{R}=\mathrm{Ac}, \mathrm{R}_{1}=\mathrm{Cbz}$

2. $\mathrm{H}_{2} / \mathrm{Pd}, \mathrm{C} \longrightarrow 4 \mathrm{R}=\mathrm{R}_{1}=\mathrm{H}$

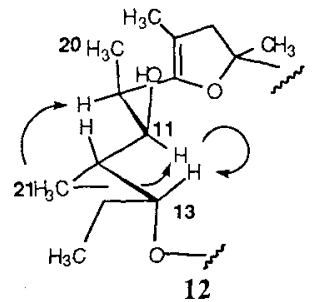

Table 1. Comparison of the ${ }^{1} \mathrm{H}$ chemical shifts of the epimeric 12-deoxy analogs.

\begin{tabular}{ccc|ccc}
\hline Proton & $\mathbf{8}$ & $\mathbf{9}$ & Proton & $\mathbf{8}$ & $\mathbf{9}$ \\
\hline 2 & 2.75 & 2.68 & $1^{\prime}$ & 4.54 & 4.64 \\
3 & 4.10 & 3.98 & $2^{\prime}$ & 4.75 & 4.76 \\
4 & 1.62 & 1.90 & $3^{\prime}$ & 2.71 & 2.74 \\
5 & 3.46 & $4^{\prime}$ & $1.67,1.27$ & $1.73,1.25$ \\
7 & $1.63,1.45$ & 2.77 & $5^{\prime}$ & 3.59 & 3.96 \\
10 & 3.57 & 2.61 & $6^{\prime}$ & 1.11 & 1.11 \\
11 & 5.55 & 3.36 & $3^{\prime}-\mathrm{NMe}_{2}$ & 2.26 & 2.28 \\
12 & 2.77 & 1.65 & $2^{\prime}-\mathrm{OAc}$ & 2.04 & 2.05 \\
13 & 5.07 & $1^{\prime \prime}$ & 4.90 & 5.13 \\
14 & $1.69,1.62$ & $1.66,1.48$ & $2^{\prime \prime}$ & $2.39,1.62$ & $2.44,1.66$ \\
15 & 0.84 & 0.89 & $4^{\prime \prime}$ & 4.46 & 4.48 \\
16 & 1.17 & 1.24 & $5^{\prime \prime}$ & 1.33 & 4.38 \\
17 & 0.96 & $6^{\prime \prime}$ & 1.21 & 1.18 \\
18 & 1.32 & $7^{\prime \prime}$ & 3.30 & 1.20 \\
19 & 1.63 & 1.30 & $3^{\prime \prime}-\mathrm{OMe}$ & 3.34 \\
20 & 1.09 & 1.54 & $4^{\prime \prime}-\mathrm{OCbz}$ & 7.36 & 5.25 \\
21 & 1.19 & 1.04 & & 5.13 & 7.35 \\
\hline
\end{tabular}


epierythromycin B) is currently under investigation and will be reported in a later communication.

\section{Dedication}

We take this opportunity to wish Professor SATOSHI ŌMURA a happy 60th birthday, long life, continued productivity and prosperity.

\section{References}

1) Ōmura, S.; K. Tsuzuki, T. Sunazuka, S. Marui, H. TOYODA, N. INATOMI \& Z. ITOH: Macrolides with gastrointestinal motor stimulating activity. J. Med. Chem. 30: $1941 \sim 1943,1987$

2) Tsuzuki, K.; T. Sunazuka, S. Marui, H. Toyoda, S. Omura, N. InAtomi \& Z. Iтoh: Motilides, macrolides with gastrointestinal motor stimulating activity $I$.
$\mathrm{O}$-substituted and tertiary $\mathrm{N}$-substituted derivatives of 8,9-anhydroerythromycin A 6,9-hemiacetal. Chem. Pharm. Bull. 37: 2687 2700, 1989

3) Kurath, P.; P. H. Jones, R. S. Egan \& T. J. Perun: Acid degradation of erythromycin A and erythromycin B. Experentia 27: 362 363, 1971

4) Barton, D. H. R.; S. W. McCombiE: A new method for the deoxygenation of secondary alcohols. J. Chem. Soc., Perkin I: $1574 \sim 1585,1975$

5) Pryor, W. A.; D. L. Fuller \& J. P. Stanley: Reactivity patterns of the methyl radical. J. Amer. Chem. Soc. 94: $1632 \sim 1638,1972$

6) Bartlett, P. D. \& R. R. Hiatt: A series of tertiary butyl peresters showing concerted decomposition. J. Amer. Chem. Soc. 80: $1398 \sim 1405,1958$

7) Klein, L. L.; L. A. Freiberg, P. Kurath \& R. F. Henry: Synthesis of (9R)-9-dihydro-6,9-anhydroerythromycin A. J. Org. Chem. 58: 3209 3212, 1993 